\title{
Parvicapsula bicornis n. sp. and P. limandae n. sp. (Myxozoa, Parvicapsulidae) in Pleuronectidae (Teleostei, Heterosomata) from Denmark
}

\author{
Marianne Køie $^{1, *}$, Egil Karlsbakk ${ }^{2,3}$, Are Nylund ${ }^{2}$ \\ ${ }^{1}$ Marine Biological Laboratory, University of Copenhagen, 3000 Helsingør, Denmark \\ ${ }^{2}$ Department of Biology, University of Bergen, PO Box 7800, 5020 Bergen, Norway \\ ${ }^{3}$ Present address: Institute of Marine Research, PO Box 1870 Nordnes, 5817 Bergen, Norway
}

\begin{abstract}
Two species of Parvicapsula were found in the kidney tubules and the urinary bladder of 2 pleuronectid fish from the northern Øresund, Denmark. The coelozoic, spherical, disporic trophozoites of both species are 10 to $12 \mu \mathrm{m}$ in diameter. The myxospores of both species are elongate, asymmetrical and slightly curved, and have spherical polar capsules. Parvicapsula bicornis n. sp. $(6-8 \times 5-6 \mu \mathrm{m}$, polar capsule $2.5 \mu \mathrm{m}$ in diameter) occurs in Pleuronectes platessa. The polar capsules of $P$. bicornis are arranged symmetrically on either side of the longitudinal axis and its spores differ from other species of Parvicapsula in having two 2-3 $\mu \mathrm{m}$ long posterior processes of different length. Parvicapsula limandae n. sp. (8-11 × 4-5 $\mu \mathrm{m}$, polar capsule $1.6 \mu \mathrm{m}$ in diameter) is found in Limanda limanda. The polar capsules are arranged along the longitudinal axis. It differs from Parvicapsula unicornis Kabata, 1962, recorded from L. limanda, in the arrangement of the polar capsules and in the absence of a posterior horn-like projection. The phylogenetic relationship between $P$. bicornis n. sp., $P$. limandae n. sp. and other Parvicapsula spp. was examined with their partial small subunit rDNA (SSU rDNA) sequences. P. limandae n. sp. and P. asymmetrica appear to be closely related, while $P$. bicornis n. sp. and P. minibicornis are the most divergent members of the genus.
\end{abstract}

KEY WORDS: Myxozoan · Parasites · Parvicapsula bicornis n. sp. · Parvicapsula limandae n. sp. · Sphaerospora irregularis · Parvicapsula unicornis · Pleuronectes platessa • Limanda limanda . SSU rRNA gene sequences · Denmark

\section{INTRODUCTION}

Eleven species of Parvicapsula Shulman, 1953 (Parvicapsulidae) have been described in marine fish (Køie 2003). The small myxospores develop in disporic trophozoites, likely pseudoplasmodia, mostly in the urinary system, with other sites being the epithelia of the gall bladder, the intestine and the pseudobranch. Since members of Parvicapsula are often pathogenic to marine fish, it is important to increase knowledge of the biology, including the life cycles, of members of this genus. Some species are pathogenic in mariculture of salmonid fish (Hoffman 1984, Kent et al. 1997, Karlsbakk et al. 2002, Sterud et al. 2003, Yasutake \& Elliott 2003, Nylund et al. 2005).

Plaice Pleuronectes platessa and dab Limanda limanda are commercially important pleuronectid flat- fish in northwestern Europe. Several myxozoan species from these hosts have been described (see e.g. Auerbach 1912, Bazikalova 1932, Shulman 1953, Shulman \& Shulman-Albova 1953, Polyanskii 1955, Kabata 1962, Gaevskaya \& Kovaleva 1984, Køie 2005). The aim of the present paper is to examine the myxozoan fauna of these pleuronectids; in particular potential pathogens in the myxosporean genus Parvicapsula.

\section{MATERIALS AND METHODS}

Pleuronectes platessa L. and Limanda limanda (L.) were bottom-trawled in the northern Øresund, Denmark, at depths of 2 to $22 \mathrm{~m}$. The plaice and dab, 42 and 39 specimens, respectively, were examined fresh. Most specimens were examined immediately upon 
capture, but some were kept in aquaria for up to $1 \mathrm{wk}$. Most organs including the musculature, the eyes, the gall bladder and urinary system were examined. Fresh squash preparations of the urinary bladder and various parts of the kidney were examined for Myxosporea. Smears were air-dried, methanol-fixed, stained with Giemsa and embedded in DPX. Measurements $(n=10)$ are based on fresh smears and are given as the mean with the range in parenthesis.

DNA was extracted from kidney tissue or urinary bladders containing Parvicapsula spp. trophozoites or spores, using the DNeasy protocol for animal tissues (Qiagen). The DNA were eluted in $100 \mu \mathrm{l}$ AE buffer supplied with the Qiagen-kit and stored at $-20^{\circ} \mathrm{C}$ before use in a PCR.

The PCR primers used were Ecf and Myxgen4r (Kent et al. 2000, Nylund et al. 2005) with additional primers constructed based on small subunit rDNA (SSU rDNA) sequences from Parvicapsula spp. and other members of the marine group of Myxosporea: forward MarF1 (RRG CGT GCC TTG AAT AAA GC) and MyxF2 (CGC GCA AAT TAC CCA ATC CAG AC), reverse LyR2 (CCT TGC GAT TGT ACT CTC CC) and MarR2 (STA GCG ACG GGC GGT GTG).

The PCR amplifications were performed in a total volume of $50 \mu \mathrm{l}$, using $2 \mu \mathrm{l}$ of template DNA and a reaction mixture consisting of $5 \mu \mathrm{l} 10 \times$ PCR buffer, $5 \mu \mathrm{l}$ $10 \mathrm{mM}$ dNTP, $2 \mu \mathrm{l}(10 \mathrm{mM})$ of the reverse and forward primer, $2 \mathrm{U}$ of thermostable DNA polymerase (Qiagen)

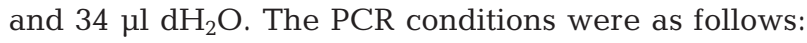
after an initial 5 min denaturation step at $95^{\circ} \mathrm{C}$, samples were taken through 35 amplification cycles, each consisting of a $30 \mathrm{~s}$ denaturation step at $94^{\circ} \mathrm{C}$, a $30 \mathrm{~s}$ primer annealing step at a temperature dependent of the primer combination used, and a $90 \mathrm{~s}$ extension step at $72^{\circ} \mathrm{C}$. A prolonged extension step of $10 \mathrm{~min}$ at $72^{\circ} \mathrm{C}$ completed each reaction.

The PCR products were purified on Qia-quick PCR Purification columns (Qiagen) and then sequenced using the BigDye Terminator Sequencing kit. The sequencing was performed using the amplification primers described above.

The sequence data were assembled with the help of VECTOR NTI software (InforMax) and GeneBank searches were done with BLAST (2.0). The VECTOR NTI Suite software package was used for multiple alignments of the partial sequences. The partial sequences of Parvicapsula bicornis (EF429097), P. limandae (EF429096) and Parvicapsula spinachiae Køie, 2003 (EF431928) (from the type host Spinachia spinachia (L.) and the type locality, northern Øresund), were aligned with homologous SSU rDNA sequences from a selected number of myxosporeans already available on the EMBL nucleotide database. In pair-wise comparisons between the different species SSU rDNA, the multiple sequence alignment editor GENEDoc (avail- able at: www.psc.edu/biomed/genedoc) was used, but the variable regions in the SSU were manually aligned to minimum divergence.

The phylogenetic relationship between Parvicapsula spp. was examined with an alignment of selected members of the marine clade (Fiala 2006). Alignments were performed with AlignX (VECTOR NTI) and manually edited in GENEDOC. Hypervariable or ambiguous regions were deleted from the alignment to ensure comparison of homologous positions. Phylogenetic analysis of the data sets were performed using PAUP* (4.0b10) (Swofford 2000) and TREePuzzLE (5.0) (Schmidt et al. 2002), using the maximum likelihood method with 100 and 10000 replicates respectively. A general time reversible (GTR) model of nucleotide substitution with a 6 category gamma distribution (GTR+ $\Gamma+\mathrm{I})$ was used following the examination of the data set with the program Modeltest (Posada \& Crandall 1998). The PAUP maximum likelihood analysis used a heuristic search algorithm with 10 random sequence additions and TBR branch swapping. Phylogenetic trees were drawn using TREEVIEW (Page 1996).

\section{RESULTS}

Two new species of Parvicapsula were found in the urinary systems of Pleuronectes platessa and Limanda limanda. All measurements below $(\mathrm{n}=10)$ give the mean with the range in parenthesis. The prevalence levels of Parvicapsula bicornis and P. limandae are reported in Table 1.

\section{Parvicapsula bicornis n. sp. (Figs. 1 \& 2)}

Syn. part. Sphaerospora irregularis Kabata, 1962 from Pleuronectes platessa.

Description: Trophozoites with mature myxospores, coelozoic, disporic and subspherical, $12 \mu \mathrm{m}$ (11 to 13 $\mu \mathrm{m})$ in diameter. Myxospores most often orientated in the same direction (Fig. 1A,B). Immature trophozoites, transparent and spherical, 2 to $10 \mu \mathrm{m}$ in diameter.

Myxospores (Figs. 1C-E and 2 A,B) 6.8 (5.5 to 7.7) $\mu \mathrm{m}$ in length (exclusive of posterior processes), and 5.3 (4.6 to 5.9) $\mu \mathrm{m}$ in maximum width. Nearly square (exclusive of posterior processes) in sutural view, i.e. from the concave (or convex) side (Figs. 1C,D \& 2A). Curved, slightly flattened in frontal view (Fig. 2B). Asymmetrical due to 2 posterior processes of different length, 2.3 (2.0 to 2.5) $\mu \mathrm{m}$ and 3.3 (3.0 to 3.5) $\mu \mathrm{m}$ in length. Processes concealed when surrounded by crystalline structures (Fig. 1E). Suture line passes on both sides from between the polar capsules along concave and convex side to half way down the longest process. 
Table 1. Prevalences (\%) of Parvicapsula bicornis n. sp. and P. limandae n. sp. in Pleuronectes platessa and Limanda limanda from the northern Øresund, Denmark, September to December 2005. For P. platessa 0-group: 5-12 cm; 1-group and older: $>23 \mathrm{~cm}$. For L. limanda 0- and 1-groups: 7-14 cm; older: $>16 \mathrm{~cm}$. Numbers of fish examined in each size group are in parenthesis

\begin{tabular}{|lcccc|}
\hline \multirow{2}{*}{ Parasite } & \multicolumn{5}{c|}{ Host } & \multicolumn{2}{c|}{\begin{tabular}{l} 
Pleuronectes platessa \\
\cline { 2 - 5 }
\end{tabular}} & $\begin{array}{c}\text { L-group } \\
\text { (20) }\end{array}$ & $\begin{array}{c}\text { 1-group and } \\
\text { older (22) }\end{array}$ & \multicolumn{2}{c}{$\begin{array}{c}\text { 0- and 1- } \\
\text { groups (15) }\end{array}$} & $\begin{array}{c}\text { Older } \\
(24)\end{array}$ \\
\hline $\begin{array}{l}\text { Parvicapsula } \\
\text { bicornis }\end{array}$ & 15 & 55 & 0.0 & 0.0 \\
$\begin{array}{l}\text { Parvicapsula } \\
\text { limandae }\end{array}$ & 0.0 & 0.0 & 47 & 79 \\
\hline
\end{tabular}

Valve nuclei at extreme posterior end of each process. Unequal valves thin-walled and smooth. Sporoplasm binucleate.

Equal spherical polar capsules close to each other 2.5 (2.3 to 2.6) $\mu \mathrm{m}$ in diameter. Plane of polar capsules perpendicular to longitudinal axis. No 'head organ'. Polar capsules open at concave side. Number of coils of polar filaments: 6 to 8 .

Type host: Pleuronectes platessa L. (Pleuronectidae).

Type locality: The northern Øresund between Helsingør and the island of Ven, 2 to $20 \mathrm{~m}$ depth, Denmark, $55^{\circ} 58^{\prime} \mathrm{N}, 12^{\circ} 38^{\prime} \mathrm{E}$.

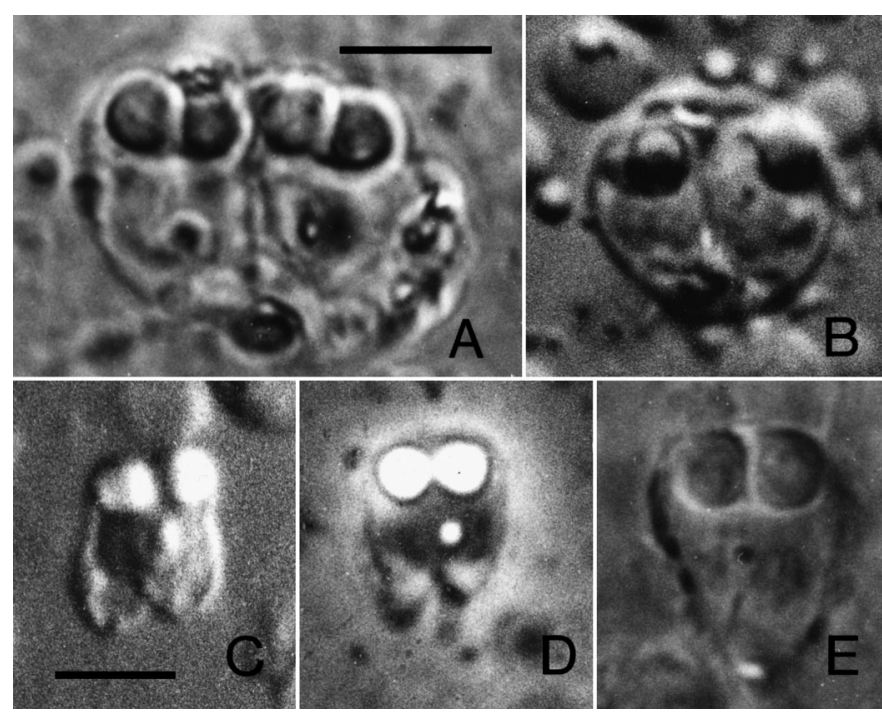

Fig. 1. Parvicapsula bicornis. Fresh squash preparation of trophozoites and myxospores in kidney tubules and urinary bladder of Pleuronectes platessa using (A-C \& E) interference contrast and (D) phase contrast. (A) Disporic trophozoite in kidney tubule. (B) Trophozoite free in urinary bladder. (C-E) Myxospore, sutural view. $(C, D)$ Myxospores free in urinary bladder. (E) Myxospore in kidney tubule. Refractive granules adhere to the surface of the spore. Note that A \& E and B-D are to the same scale. Scale bars $=5 \mu \mathrm{m}$
A

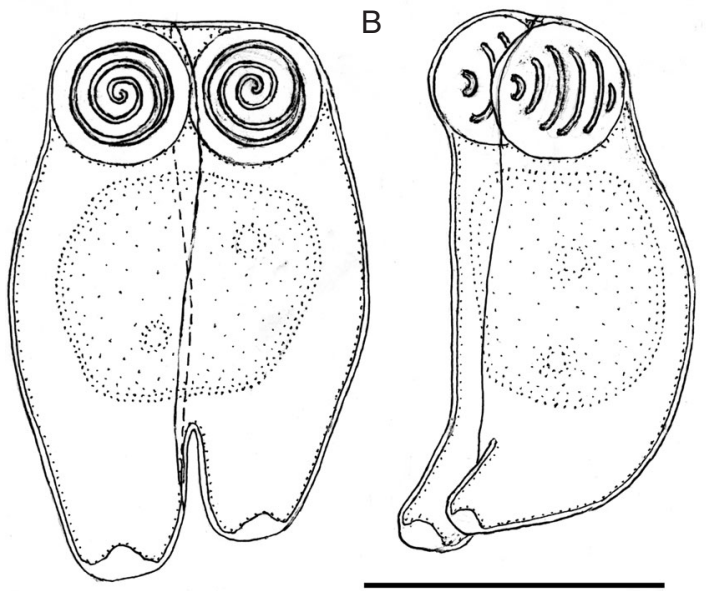

Fig. 2. Parvicapsula bicornis. Myxospore. (A) Sutural view, seen from the concave side. (B) Frontal view. Scale bar $=5 \mu \mathrm{m}$

Prevalence: $36 \%$ (15 of 42) of plaice examined from September to December 2005 (Table 1). Only 20\% of the infected fish had mature spores in the urinary bladder.

Type material: Giemsa-stained smears are deposited at the Zoological Museum, Copenhagen, Denmark. The museum does not use catalogue numbers.

Etymology: The species name refers to the 2 posterior processes.

Site and host reaction: All developmental stages, coelozoic in the kidney tubules and Bowman's capsules, were surrounded by elongated, highly refractive crystalline granules of host origin (Fig. 1A,E). The granules sometimes completely covered trophozoites or myxospores. The chemical nature of these granules and their effect on the parasites are unknown.

Comments: Based on spore morphology, host, and geographical location, the myxosporean reported here is a new species of Parvicapsula, Parvicapsula bicornis n. sp. It has the characteristics of the family Parvicapsulidae Shulman, 1953 (Lom \& Dyková 1992, Køie 2003). P. bicornis differs from all known species of Parvicapsula (see Køie 2003) in having both spherical polar capsules and 2 posterior processes of different length.

The partial SSU rDNA sequence of Parvicapsula bicornis shows highest identity to $P$. unicornis and P. pseudobranchicola, with highest percent overall identity (including indels) with the former, and highest percent identity by aligned bp with the latter (Table 2). However, the P. bicornis sequence differs in a number of substitutions at positions conserved across the other Parvicapsula spp., reflected in the phylogenetic analysis by a basal position in the Parvicapsula clade (see Fig. 5). 
Table 2. Comparison of the partial SSU rRNA gene sequences from Parvicapsula bicornis (EF429097) and P. limandae (EF429096) with other Parvicapsula spp. Percent sequence identity (PID) was calculated as identity by aligned bp (PIDa) and overall identity (including indels) (PIDo). nt: nucleotides

\begin{tabular}{|c|c|c|c|c|c|c|}
\hline & $\begin{array}{c}\text { Parvicapsula } \\
\text { minibicornis } \\
\text { (AF201375) }\end{array}$ & $\begin{array}{l}\text { Parvicapsula } \\
\text { spinachiae } \\
\text { (EF431928) }\end{array}$ & $\begin{array}{c}\text { Parvicapsula } \\
\text { unicornis } \\
\text { (AY584190) }\end{array}$ & $\begin{array}{c}\text { Parvicapsula } \\
\text { pseudobranchicola } \\
\text { (AY308481) }\end{array}$ & $\begin{array}{c}\text { Parvicapsula } \\
\text { asymmetrica } \\
\text { (AY584191) }\end{array}$ & $\begin{array}{c}\text { Parvicapsula } \\
\text { limandae }\end{array}$ \\
\hline \multicolumn{7}{|l|}{ Parvicapsula bicornis } \\
\hline Alignment, length (nt) & 1410 & 1368 & 1274 & 1303 & 1297 & 1230 \\
\hline Aligned bp & 1237 & 1235 & 1238 & 1236 & 1237 & 1169 \\
\hline Identities (nt) & 1063 & 1059 & 1049 & 1070 & 1063 & 1001 \\
\hline Insertions/deletions (nt) & $4 / 169$ & $6 / 127$ & $3 / 33$ & $2 / 65$ & $1 / 59$ & $1 / 60$ \\
\hline PIDo (\%) & 75.4 & 77.4 & 82.3 & 82.1 & 82.0 & 81.4 \\
\hline PIDa (\%) & 85.9 & 85.7 & 84.7 & 86.6 & 85.9 & 85.6 \\
\hline \multicolumn{7}{|l|}{ Parvicapsula limandae } \\
\hline Alignment, length (nt) & 1361 & 1322 & 1239 & 1232 & 1226 & \\
\hline Aligned bp & 1229 & 1242 & 1210 & 1224 & 1225 & \\
\hline Identities (nt) & 1060 & 1098 & 1115 & 1166 & 1216 & \\
\hline Insertions/deletions (nt) & $13 / 119$ & $9 / 71$ & $29 / 0$ & $2 / 6$ & $1 / 0$ & \\
\hline PIDo (\%) & 77.9 & 83.1 & 90.0 & 94.6 & 99.2 & \\
\hline PIDa (\%) & 86.2 & 88.4 & 92.1 & 95.3 & 99.3 & \\
\hline
\end{tabular}

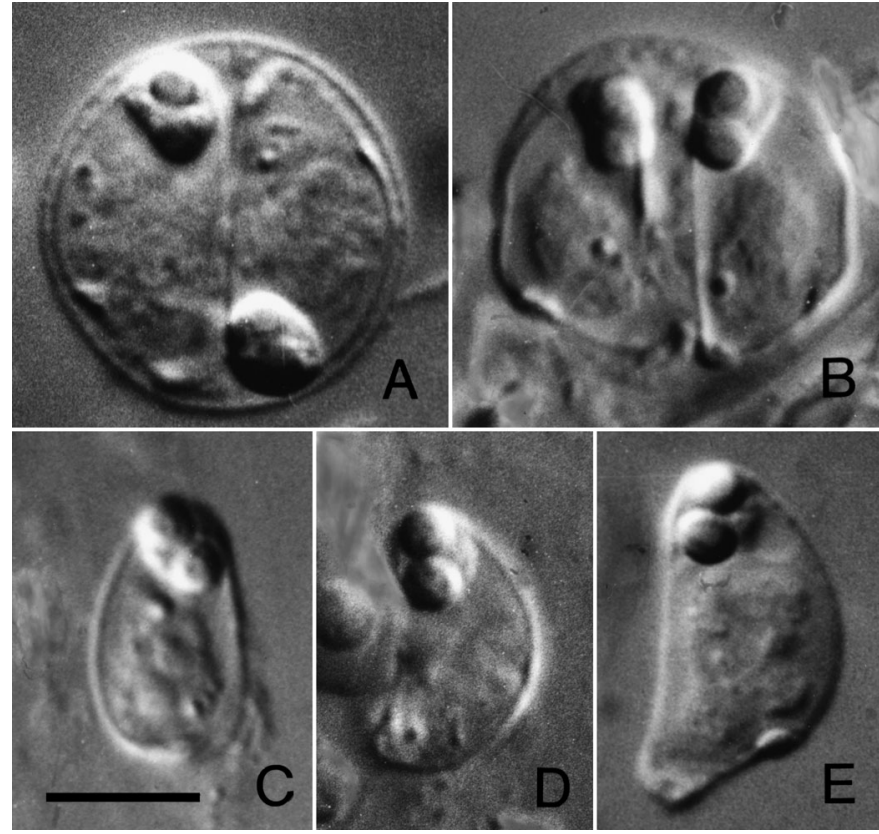

Fig. 3. Parvicapsula limandae, fresh squash preparation of trophozoites and myxospores in the urinary bladder of Limanda limanda using interference contrast. (A,B) Trophozoites. (C) Myxospore, frontal view. (D) Myxospore, oblique view, close to blood cell. (E) Myxospore, lateral view. Scale bar $=5 \mu \mathrm{m}$

\section{Parvicapsula limandae n. sp. (Figs. 3 \& 4)}

Syn. part. Parvicapsula unicornis Kabata, 1962 from Limanda limanda.

Description: Trophozoites with fully developed myxospores, coelozoic, disporic and spherical, 10.5 (10 to 11) $\mu \mathrm{m}$ in diameter. Spores most often oriented in same direction and with concave sides facing each other
(Fig. 3A,B). Immature trophozoites, transparent and spherical, 2 to $8 \mu \mathrm{m}$ in diameter. Myxospores 9.5 (8.3 to 10.8$) \mu \mathrm{m}$ in length and 4.7 (4.3 to 5.4) $\mu \mathrm{m}$ in maximal width. Ovoid to pyriform in frontal view or medial plane, i.e. from the concave (or convex) side (Figs. 3C \& 4A). Polar capsules on longitudinal axis. Frontal view of spores occasionally slightly asymmetrical as polar capsules may be displaced from longitudinal axis.

Spores asymmetrical (curved) in lateral or sutural view (Figs. 3D,E \& 4B). Suture line from between polar capsules along lateral sides to convex side. Suture lines unite 3 to $4 \mu \mathrm{m}$ from posterior end and slightly posterior to nucleus of anterior valve cell. Nucleus of posterior valve cell at extreme posterior end. Unequal valves, thinwalled and smooth. Sporoplasm binucleate.

Spherical polar capsule, 1.6 (1.5 to 1.6) $\mu \mathrm{m}$ in diameter close to each other. Polar capsules in a prominent spherical 'head organ', twice the diameter of polar capsules. Polar capsules open at concave side. Polar filaments with 6 to 8 coils.

Type host: The only known host is the common dab Limanda limanda (L.) (Pleuronectidae).

Type locality: The northern Øresund between Helsingør and the island of Ven, 16-20 m, Denmark, $55^{\circ} 58^{\prime} \mathrm{N}, 12^{\circ} 38^{\prime} \mathrm{E}$.

Type material: Giemsa-stained smears are deposited at the Zoological Museum, Copenhagen, Denmark. The museum does not use catalogue numbers.

SSU rDNA sequence: EF429096 (partial).

Etymology: The species name refers to the name of its fish host.

Prevalence of infection: $67 \%$ (26 of 39) specimens of Limanda limanda examined from September to 
A

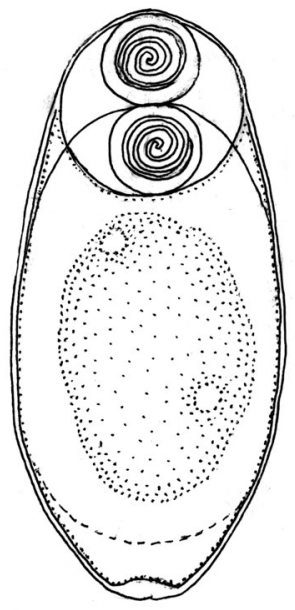

B

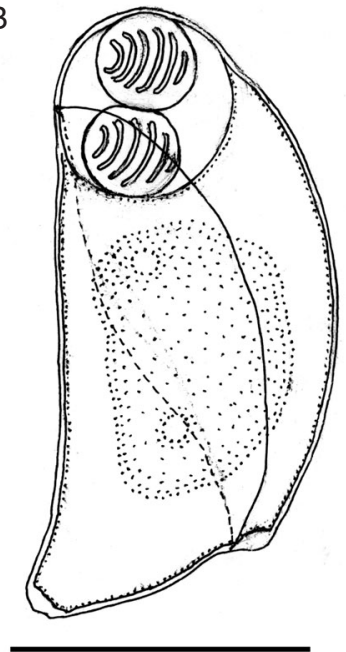

Fig. 4. Parvicapsula limandae. Myxospore in (A) frontal view, seen from the concave side and (B) lateral view. Scale bar = $5 \mu \mathrm{m}$

December 2005 (Table 1). Less than $10 \%$ of the infected fish had mature spores in the urinary bladder.

Site and host reactions: Immature, spherical, transparent trophozoites 2 to $8 \mu \mathrm{m}$ in diameter occur coelozoic in kidney tubules and Bowman's capsules. Trophozoites with mature spores and free myxospores in kidney tubules and urinary bladder. Even though the kidney tubules and Bowman's capsules were dilated due to numerous small transparent trophozoites, no host reaction was observed.

Comments: Parvicapsula limandae n. sp. has the characteristics of the family Parvicapsulidae Shulman, 1953 (Lom \& Dyková 1992, Køie 2003). Only 2 of the previously described species of Parvicapsula have (sub)spherical polar capsules which are arranged at the longitudinal axis of the spore (see Køie 2003). P. limandae is most similar to Parvicapsula sp. in the kidney of Oncorhynchus kisutch from the northern US Pacific (Hoffman 1984), as described from the appearance of the spores in sections. Since Parvicapsula sp. has recently also been detected in pseudobranch tissue (Yasutake \& Elliott 2003), that species may be closely related to the similar $P$. pseudobranchicola Karlsbakk et al. 2002, which typically occurs in the pseudobranchs of Salmo salar in Norway (Karlsbakk et al. 2002, Sterud et al. 2003). P. pseudobranchicola also has subsphaerical polar capsules and shows a prominent 'head organ', but is larger that $P$. limandae sp.n. and clearly distinct from it by the low SSU rDNA sequence similarity (95\%).

Parvicapsula limandae n. sp. has a superficial resemblance to $P$. unicornis Kabata, 1962 found inamong others - L. limanda from the northern North Sea (Kabata 1962). P. unicornis differs from the present species primarily in that it has a long posterior projection and in that the polar capsules are arranged transverse to the longitudinal axis.

Parvicapsula limandae n. sp. shows a high sequence similarity with a $P$. asymmetrica Shulman, 1953 sequence from the type host Cyclopterus lumpus (cf. Nylund et al. 2005) (see Fig. 5 which also shows the phytogenetic position of $P$. bicornis). P. asymmetrica is a larger species, with spherical trophozoites 17-21 $\mu \mathrm{m}$ in diameter, spores $10.5-17 \times 6-9 \mu \mathrm{m}$, pyriform polar capsules, rounded posterior end and a suture line that posteriorly unites terminally or subterminal-ventrally (Shulman 1953, Shulman \& Shulman-Albova 1953). Based on spore morphology, and our knowledge on intraspecific variation in myxospores, conspecificity of $P$. limandae and P. abyssorum is highly unlikely. We recently reproduced the $P$. asymmetrica sequence from a Parvicapsula-infected C. lumpus caught near Bergen (W. Norway). Identical P. limandae sequences were obtained from 3 individual Limanda limanda only infected with $P$. limandae in their urinary system and caught at the same locality at different times of the year. Hence, we appear to have a case with 2 morphologically dissimilar Parvicapsula spp. that show related SSU rDNA sequences. The unambiguous differences found represent 4 pyrimidine transitions, one purine transition and one transversion in the V4 region, 2 transversions in the $\mathrm{V} 7$ region and a purine transition in the $\mathrm{V} 8$ region.

\section{DISCUSSION}

Parvicapsula bicornis n. sp. and P. limandae n. sp. are members of the family Parvicapsulidae and the genus Parvicapsula (Lom \& Dyková 1992). Both new species of Parvicapsula have apparently been recorded from their respective hosts previously.

Sphaerospora irregularis Kabata, 1962 was recorded in 0- and 1-group Pleuronectes platessa from farm environments off western Scotland (MacKenzie et al. 1976). It is likely that this myxozoan should be identified as Parvicapsula bicornis, which has large polar capsules and a superficial resemblance to $S$. irregularis Kabata, 1962 described from the urinary bladder of Hippoglossoides platessoides (Fabricius) (syn. Drepanopsetta platessoides) from the northern North Sea (Kabata 1962). Kabata (1962) placed the new species tentatively in the genus Sphaerospora. Gaevskaya \& Kovaleva (1984) transferred $S$. irregularis to the genus Myxoproteus based on the original description by Kabata (1962). However, Arthur \& Lom (1985), without having reexamined the species from the type host, transferred $S$. irregularis to the genus Ortholinea. S. irregularis has apparently only been found in $H$. 


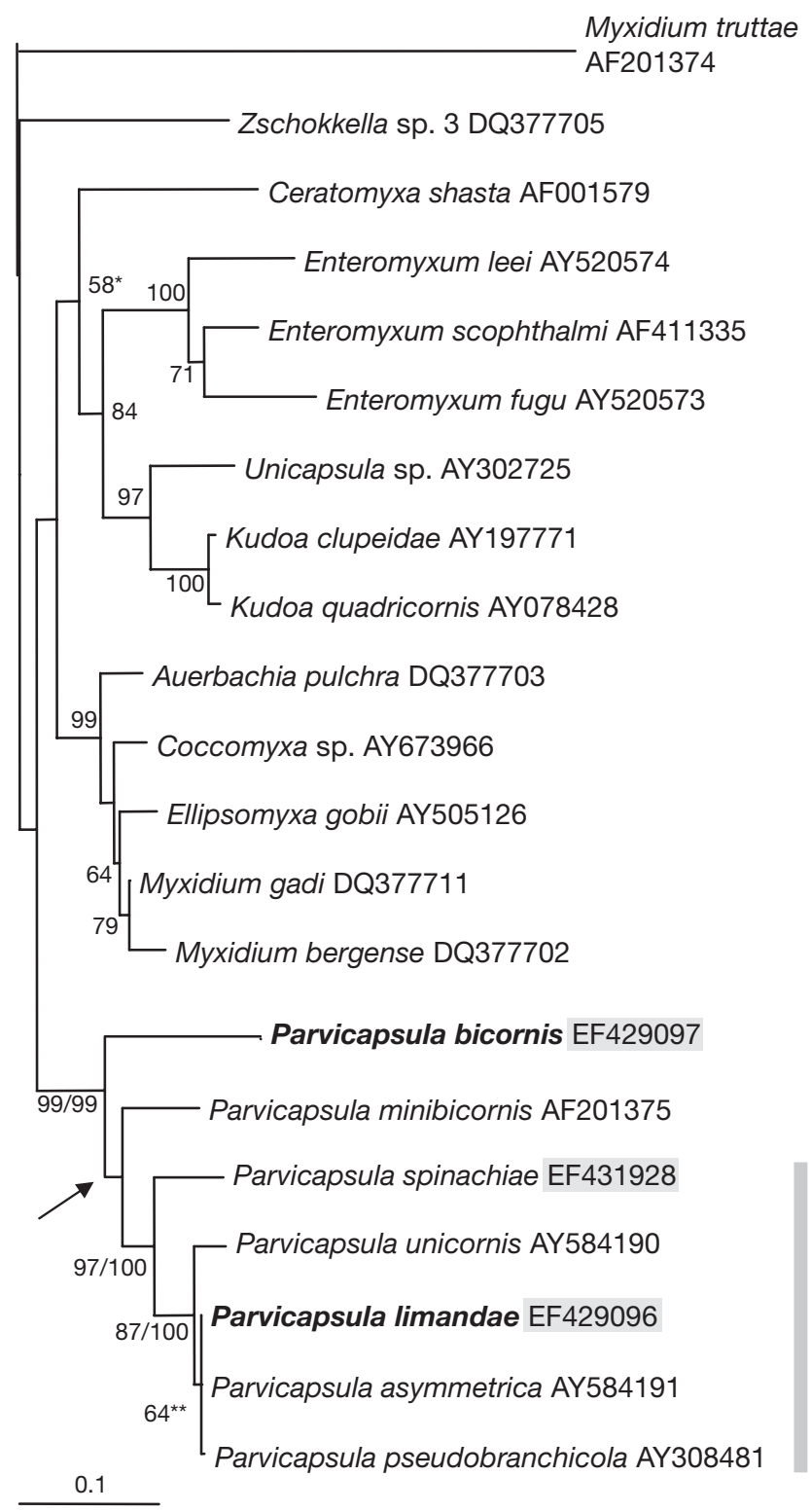

Fig. 5. Maximum likelihood distance tree, based on alignment of SSU rDNA sequences from 21 taxa with 965 characters, constructed using PAUP 4.0b10. Rooted with Myxidium truttae. Support values at nodes; ML bootstrap (PAUP). In the Parvicapsula clade, quartet puzzling (QP) support values (SV) are also shown except in ambiguous nodes $\left({ }^{*}\right)$. Only support values above $50 \%$ shown. The topology of the QP tree did not agree in the position of Ceratomyxa shasta, placed as a sister group to the others (DQ377705) with poor support (SV 58), or in placing P. minibicornis as a sister group to the other Parvicapsula spp. with strong support (SV 99). Arrow: the interrelationship between $P$. bicornis, $P$. minibicornis and the branch with the remaining Parvicapsula spp. ('core' group, gray vertical line) is not resolved in PAUP; $P$. bicornis sister group to the core group with SV 91 in QP. $\left({ }^{* *}\right)$ the interrelationship between the 3 species in the terminal node (QP) is as follows: P. pseudobranchicola sister to $P$. limandae and $P$. asymmetrica (SV 74), the latter 2 species grouped with SV 90. Bar: 0.1 substitutions per site platessoides by Kabata (1962). It is possible that reexamination of $S$. irregularis will show this species to belong to Parvicapsula.

Myxoproteus caudatus Shulman, 1953 in Limanda limanda has, apart from the filamentous caudal projection and some distance between the polar capsules, also some resemblance to Parvicapsula bicornis. This species has only been found in the White Sea and the Barents Sea (Shulman 1953, Polyanskii 1955).

Kabata (1962) described Parvicapsula unicornis from Callionymus lyra L. (Callionymidae), Limanda limanda L. (Pleuronectidae) and Lepidorhombus whiffiagonis (Walbaum) (Scophthalmidae). Kabata (1962) found the new species in 4 of $60 \mathrm{C}$. lyra, but in only 1 of 55 and 1 of $46 \mathrm{~L}$. limanda and $L$. whiffiagonis, respectively. The genus Parvicapsula is apparently highly host specific, probably to genus and sometimes to species level. It is unlikely that $P$. unicornis occur in 3 different fish families. It is expected that the description by Kabata (1962) is based on specimens found in the first mentioned and most heavily infected host. Since Callionymus lyra is the first listed host, this species should be regarded as the type host of $P$. unicornis. The specimens found in L. limanda by Kabata (1962) might be identical with $P$. limandae, which superficially has some resemblance to $P$. unicornis. It would be interesting to know whether $L$. whiffiagonis is infected with a third species of Parvicapsula.

Plaice Pleuronectes platessa and dab Limanda limanda are common in the northern Øresund. The 0groups of plaice were infected with Parvicapsular bicornis, indicating that these fish acquire the infection in shallow water above the halocline, which occurs at depths of 10 to $15 \mathrm{~m}$, and that the invertebrate hosts probably live here. The salinities above and below the halocline are 12 to $20 \%$ and 25 to $30 \%$, respectively. On the other hand, the small specimens of dab live on the muddy bottom below the halocline and since they are infected with Parvicapsula limandae, the invertebrate hosts probably live in this area.

Acknowledgements. Heidrun Plarre (BiO, $\mathrm{UiB})$ is thanked for help with the PCR work.

\section{LITERATURE CITED}

Arthur JR, Lom L (1985) Sphaerospora araii n. sp. (Myxosporea: Sphaerosporidae) from the kidney of a longnose skate (Raja rhina Jordan and Gilbert) from the Pacific Ocean off Canada. Can J Zool 63:2902-2906

Auerbach M (1912) Studien über die Myxosporidien der norwegischen Seefische und ihre Verbreitung. Zool Jahrb Abt Syst Oekol Geogr Tiere 34:1-50

Bazikalova A (1932) Contribution to the parasitology of Murman fishes. Sb Nauchn Prom Rab Murm 1932:135-153 (in Russian) 
Fiala I (2006) The phylogeny of Myxosporea (Myxozoa) based on small subunit ribosomal RNA gene analysis. Int J Parasitol 36:1521-1534

Gaevskaya A, Kovaleva A (1984) Addition to the myxosporidian fauna (Protozoa: Myxosporidia) of fish of the Northeast Atlantic. Gidrobiol Zh 20(3):49-53 (in Russian)

Hoffman GL (1984) Two fish pathogens, Parvicapsula sp. and Mitraspora cyprini (Myxosporea) new to North America. Symp Biol Hung 23:127-135

Kabata Z (1962) Five new species of Myxosporidia from marine fishes. Parasitology 52:177-186

Karlsbakk E, Sæter PA, Høstlund C, Fjellsøy KR, Nylund A (2002) Parvicapsula pseudobranchicola n.sp. (Myxozoa), a myxosporidian infecting the pseudobranch of cultured Atlantic salmon (Salmo salar) in Norway. Bull Eur Assoc Fish Pathol 22:381-387

Kent ML, Whitaker DJ, Dawe SC (1997) Parvicapsula minibicornis n. sp. (Myxozoa, Myxosporea) from the kidney of sockeye salmon (Oncorhynchus nerka) from British Columbia, Canada. J Parasitol 83:1153-1156

Kent ML, Khattra J, Hedrick RP, Devlin RH (2000) Tetracapsula renicola n. sp (Myxozoa: Saccosporidae); the PKX myxozoan - the cause of proliferative kidney disease of salmonid fishes. J Parasitol 86:103-111

Køie M (2003) Parvicapsula spinachiae n. sp. (Myxozoa, Parvicapsulidae) in Spinachia spinachia (L.) (Teleostei, Gasterosteidae) from Denmark. Parasitol Res 90:445-448

Køie M (2005) Trilosporoides platessae gen. et sp. n. (Myxozoa: Multivalvulida) in the plaice Pleuronectes platessa from Denmark. Folia Parasitol 52:304-306

Lom J, Dyková I (1992) Protozoan parasites of fishes. Elsevier, Amsterdam

MacKenzie K, McVicar AH, Waddell IF (1976) Some parasites

Editorial responsibility: Dieter Steinhagen,

Hannover, Germany of plaice Pleuronectes platessa L. in 3 different farm environments. Scott Fish Res Rep 4:1-14

Nylund A, Karlsbakk E, Sæether PA, Koren C and 7 others (2005) Parvicapsula pseudobranchicola (Myxosporea) in farmed Atlantic salmon Salmo salar: tissue distribution, diagnosis and phylogeny. Dis Aquat Org 63:197-204

Page RDM (1996) TREEVIEW: an application to display phylogenetic trees on personal computers. Comput Appl Biosci 12:357-358

Polyanskii Yu (1955) Parasites of the fish of the Barents Sea. Tr Zool Inst Leningr 19:1-170 (in Russian, English translation by Israel program for scientific translations, Jerusalem 1966)

Posada D, Crandall KA (1998) Modeltest: testing the model of DNA substitution. Bioinformatics 14:817-818

Schmidt HA, Strimmer K, Vingron M, von Haeseler A (2002) TREe-PuzzLE: maximum likelihood phylogenetic analysis using quartets and parallel computing. Bioinformatics 18:502-504

Shulman SS (1953) New and poorly studied myxosporidians of the White Sea. Zool Zh 32: 384-394 (in Russian)

Shulman SS, Shulman-Albova RE (1953) Parasites of fishes of the White Sea. Izdat Akad Nauk SSSR, Moskva, (in Russian)

Sterud E, Simolin P, Kvellestad A (2003) Infection by Parvicapsula sp. (Myxozoa) is associated with mortality in seacaged Atlantic salmon Salmo salar in northern Norway. Dis Aquat Org 54:259-263

Swofford DL (2000) PAUP*, phylogenetic analysis using parsimony $\left({ }^{*}\right.$ and other methods), version 4 . Sinauer Associates, Sunderland, MA

Yasutake WT, Elliott DG (2003) Epizootiology and histopathology of Parvicapsula sp. in coho salmon Oncorhynchus kisutch. Dis Aquat Org 56:215-221

Submitted: June 16, 2006; Accepted: January 3, 2007

Proofs received from author(s): June 21, 2007 